\title{
Effects of Work-life Balance Policies on Corporate Performance and the Promotion of Female Employee
}

\author{
Mamiko Takeuchi ${ }^{1}$ \\ ${ }^{1}$ Office for the Promotion of Gender Equality, Fukuoka, Japan \\ Correspondence: Mamiko Takeuchi, Office for the Promotion Gender Equality, Fukuoka, Japan, 744 Motooka \\ Nishi-ku Fukuoka 819-0395, Japan. E-mail: takeuchi@danjyo.kyushu-u.ac.jp
}

Online Published: September 6, 2018

doi:10.5539/ijbm.v13n10p9

URL: https://doi.org/10.5539/ijbm.v13n10p9

\begin{abstract}
Based on a survey conducted among Japanese pharmaceutical companies, this study analyzes the processes and influence of work-life balance policies on the promotion of women employees and corporate performance as a result of women's activities. Structural equation modeling is used to clarify the complex causality between the promotion of women employees and personnel policies. The results of our analysis indicate that even if the complex relationships among the variables are considered, productive improvements from work-life balance policies are not observed. Although work-life balance policies do not have a direct effect on the promotion or wages of women, they have an indirect effect on women's promotions and wage increases over the length of their tenure.
\end{abstract}

Keywords: structural equation modeling, work-life balance policy, women's career advancement, corporate performance

\section{Introduction}

Among developed countries, Japan is often said to be less advanced in providing equal opportunities for female workers. The Global Gender Gap Index (GGGI) indicates that Japan ranked 111 th among 144 countries in 2016. This measure, formulated by the World Economic Forum (WEF), indicates the inequality between male and female workers in Japanese society.

The government and private companies have attempted to develop women-friendly working conditions through efforts such as formulation of the Equal Employment Opportunity Law, promotion of affirmative action, prevention of sexual harassment, and implementation of work-life balance (WLB) policies. Figure 1 illustrates that the percentages of female managers, such as subsection chief, section chief, and division chief, have been gradually increasing, and the percentages more than doubled for these positions from the year 2000 to 2016 (Cabinet Office, 2017). At the same time, Figure 2 shows that the percentages of female monthly salary to Male counterparts, the gap between male and female monthly salary has been narrowed during the same period as Figure1. (Cabinet Office, 2017). 


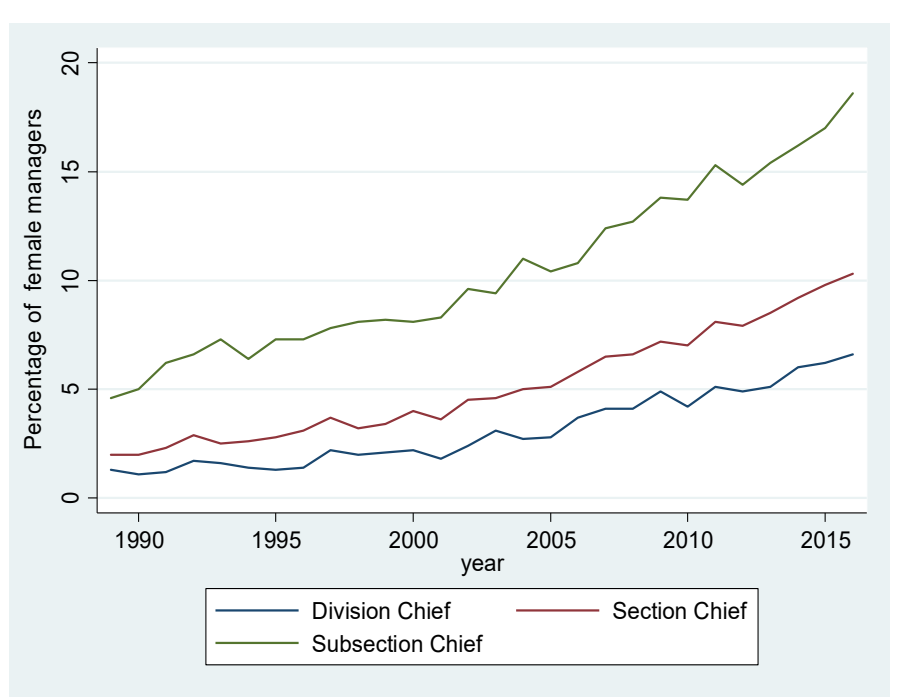

Figure 1. Percentage of female managers in private enterprises from 1990 to 2016 in Japan

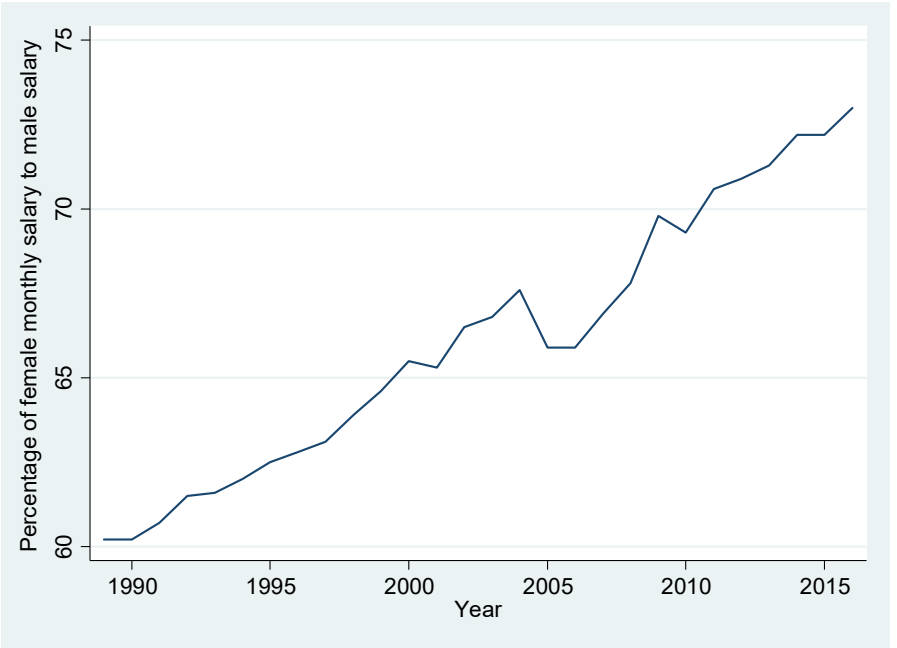

Figure 2. Percentage of female monthly salary to male salary from 1990 to 2016 in Japan (full-time workers)

However, this does not mean that there is a clear correlation between proactive policy support for female workers in Japan and either the growing percentage of female managerial personnel or the increase in female salaries. Thus, explanations of the primary reasons for the noticeably low percentage of Japanese female managerial personnel compared to those of other countries are insufficient. One reason for this is the lack of a substantial accumulation of demonstrative analytical data to evaluate the related hypotheses. To overcome this problem, this study uses matched data from company and employee information and structural equation modeling (SEM) for the main analysis to examine the causality of these variables.

This paper is structured as follows: The second section reviews preceding studies and explains how this study contributes to future research on the conditions of female workers. The third section discusses how personnel policies have affected the percentage of female managerial personnel and, ultimately, companies' business performance. The fourth section examines analytical data and presents the results. The fifth section concludes the paper.

\section{Literature Review}

One of the research subjects of female employment in the Japanese labor market is the wage differential between male and female workers. Tomita (1988) notes that gender gaps in wage profile gradients in industries are smaller when there is less gender discrimination with regard to recruitment and personnel relocation in the same 
company. Higuchi (1991) notes that there are smaller gender gaps of employment year wage profiles in industries where equal treatment or utilization of the female workforce is more likely to be conducted in job training. Additionally, Mitani (1996) shows that gender gaps in wage profiles are smaller in companies that conduct more gender-equal employment management.

Recent studies in Japan consider the positive utilization of the female workforce and WLB policies. Frequently noted is that many Japanese female workers interrupt their careers in their late twenties to get married and care for their children (Ōsawa, 1993). Early retirement of these female workers causes the undesirable suspension of their careers. These workers break away from employment before the costs of substantial job training and resources are recouped. This is considered one of the major factors preventing companies' aggressive use of the female workforce. Therefore, to promote female employment, it is essential to create an environment where childbirth and child care do not obstruct the continuation of women's careers. Recent researchers have begun to recognize the necessity of balancing work with private life.

One of the policies that could be important in making a difference with respect to this issue is the child care leave system. There have already been a considerable number of studies on the effect of this initiative. Shigeno and Okusa (1998) demonstrate that the child-rearing leave system facilitates continuous female employment. Morita and Kaneko (1998) note that the system is effective for boosting continuous female employment.

In addition to the child care leave system, efforts have been made to ensure diverse and flexible personnel management, which facilitates work-life balance (WLB). One such innovative approach is WLB policies. Sakazume (2002) shows that WLB policies are effective in boosting worker morale, improving working conditions, and reducing the percentage of women leaving the work force in Japan.

Recent studies have paid keen attention to the effect of WLB policies on corporate performance. Many companies have tended to consider utilization of female workers, but WLB policies would place a heavier financial burden on their business and be insufficient to warrant active implementation. However, comparative studies among countries have been promoted in recent years and demonstrate that there are no negative correlations between female employment and economic performance. For example, Perry-Smith and Blum (2000) postulate that WLB policies have a positive impact on organizations as a mechanism for a competitive advantage. Additionally, Shepard, Clifton, and Kruse (1996) note that companies with a flexible employment structure, such as flextime, can increase their productivity by $10 \%$ compared to companies without such systems, which suggests that more flexible employment systems lead to productivity improvement.

Because work-life initiatives encompass a variety of practices that aid workers in balancing the demands of work and personal life (Lobel \& Kossek, 1996); family-friendly policies are thought to be included in work-life balance policies (Beauregard \& Henry, 2009). Organizations can enhance their ability to recruit and retain a top-quality workforce if they provide employees with flexibility and resources to help them more easily combine work and family (Greenhaus \& Parasuraman, 1999; Lobel, 1999). Providing work schedule flexibility reduces the level of work-family conflict (Hammer, Allen, \& Grigsby, 1997) and enhances satisfaction with family life (Parasuraman, Purohit, Godshalk, \& Beutell, 1996).

This has caused some Japanese researchers to argue that the active use of female employees and WLB policy initiatives will have a positive impact on corporate performance in Japan, as well as in other countries (Higuchi, Asami, Hirakawa, Ōzeki, \& Mori, 2006). Amid these trends, some scholars, such as Takeishi (2006) and Wakisaka (2006), have identified a positive relationship between WLB and firm productivity in surveys of Japanese companies. On the other hand, Yamamoto and Matsuura (2012) note that the correlation between WLB and firm productivity in Japan is explained by firm heterogeneity.

Although there are many studies on female employment, many tasks still require consideration. Our contributionis how to specify the causality between personnel management and corporate performance. For example, it is conceivable that a company could gain remarkable achievements by introducing WLB policies. At the same time, however, there is a possible scenario in which a company can afford to introduce WLB policies because other factors have contributed to high performance. It is necessary to closely examine the causality between WLB policies and corporate performance to correctly interpret the situation. Moreover, several steps are required before intra-corporate measures can have substantial effects on easing gender gaps in wages and promotions. However, only a small amount of analytical data exists on this subject.

Many previous studies are based either on individual or company survey data. The survey data from individuals include the possibility that individual employees may not have accurate information about the personnel policies of their company. Information about personnel systems must be collected from companies for information accuracy. However, it is more appropriate to collect information about the attributes of workers directly from 
individual employees, and it is particularly desirable to obtain personal information from individuals, such as wages and promotions and psychological information, including work motivation. Therefore, an analysis that matches these two survey patterns is more valid. With a focus on this critical point, this study has the substantial advantage of being based on matched data for both companies and individual workers.

\section{Main Analytical Method}

This study uses structural equation modeling (SEM) for the primary data analysis; SEM is a form of statistical methodology used to examine the causality of social and natural phenomena.

This method handles latent variables that cannot be directly measured and stems from confirmatory factor analysis espoused by Joreskog and Lawley (1968) and Joreskog (1969). The significance of analyzing covariance structures was subsequently recognized, and this recognition developed into examining causality among constituent factors by integrating path analysis and confirmatory factor analysis. Then, Joreskog (1978) devised the linear structure relations (LISREL) model. This method was originally used in educational and psychological realms and has also been utilized in business administration and economics. There could be complicated relationships among variables; for example, between career development through female job rotation and specific vocational training measures for women and the percentages of female employment and sales per employee associated with WLB policies. There may also be correlations between female promotion and morale and sales per employee. Thus, the validity of these correlations should be statistically examined. Applied studies using the SEM method include the effect of predictive emotional reactions on actions (Richard, van der Pligt, \& de Vries, 1996), the effect of evaluation criteria for public policies on individlual behaviors (Maurer, Park, \& Judd, 1996), an individual's psychological tendency to show sympathy or delighit for others' misfortune (Brigham, Kelso, \& Jackson, 1997), decisive factors on consumers' garbage disposal (Taylor \& Todd, 1997), changes in awareness among university students with part-time jobs as private tutors (Fresko, 1997), and physical exercise for health maintenance (Fuchs, 1996).

This method is necessary because of the complicated causality between WLB policies and other variables. Many of the preceding studies focus on the isolated effects of WLB policies on motivation and morale of

among these factors is not always in the same direction. Multiple directions can be considered, and inverse directions could be supported. Figure 3 illustrates the paths of the covariance structure analyses of the relationship between WLB policies and female employment.

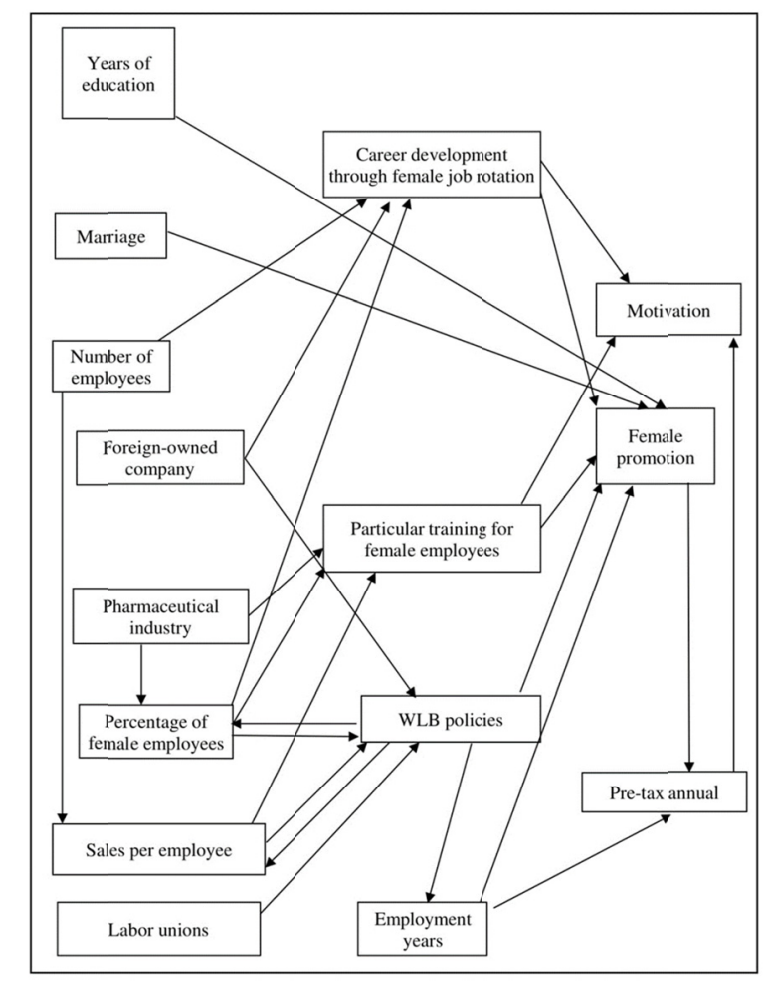

Figure 3. Structural equation modeling of WLB policies 
The effective implementation of WLB policies in the working environment facilitates female employment, that is, the percentage of female workers is likely to rise. There could also be a reverse causal relation between the number of female employees and workplace policies, that is, if many female employees continue working without a mid-career interruption, companies might think of introducing WLB policies to effectively utilize the female workforce and create better working conditions for them.

In addition, it is conceivable that there could be multiple relationships among WLB policies, business productivity, and corporate performance. Companies can secure a pool of more capable female workers by introducing WLB policies, and female workers in high-level positions can contribute to increasing corporate performance. However, if an enterprise in a tight management condition perceives WLB actions as a heavy burden, that enterprise would not launch such policies. Alternatively, some companies that perform well can afford to introduce WLB policies. Sales per employee and percentage of female employment could both conceivably be connected to WLB policies. Thus, the relationships among variables could be considerably complicated, as illustrated in Figure 3. The figure is based on observed variables, not latent variables. The arrow marks checked in both directions between the variables indicate correlation and covariation, and the relationships are insufficiently clear to identify causality. The analysis of the model is conducted using a chi-squared test, the most common statistical method, and the hypothesis that the path coefficient is 0 is based on Wald statistics. Moreover, the path coefficient from erroneous variables is set as 1 for distinguishability. For the assessment of the whole covariance structure analysis model, indexes such as the goodness of fit index (GFI), Akaike's information criteria (AIC), and route mean square error of approximation (RMSEA) are often used. In this study, the validity of the model is measured using a chi-squared test.

\section{Data and Results}

This section examines the relationship between personnel management of women and other variables based on the arguments in the previous section. In particular, this section investigates whether WLB policies can lead to better corporate performance and lead to better female promotion.

This study refers to matched data based on the Fact-finding Survey on Employment Management focusing on companies listed in the Report on the Employment Promotion Measures for the Pharmaceutical Industry and the Survey on The Employees' Awareness conducted for employees working in the companies.

These surveys were conducted in 1995. The survey on employment management focused on 230 member companies of the Pharmaceutical Manufacturers' Association of Tokyo and 270 member companies of the Osaka Pharmaceutical Manufacturers Association. Survey forms were distributed to the enterprises by post, and the completed forms were collected by the same method. Valid responses were collected from 310 companies, and the percentage of collection was $62 \%$. The survey forms on employees' awareness were internally distributed to 5,000 full-time employees of 120 companies primarily engaged in pharmaceutical operations among the 310 organizations that gave valid responses to the survey on employment management. The completed forms were collected in the same way. Responses were obtained from 3,462 workers of 102 companies, and the percentage of collection was $69.2 \%$.

Our analyses calculated the percentage of extraction for each company from the number and sample number of female employees and re-extracted, allowing redundant data to restore the population. However, the sample size excluded cases in which only a few samples of employees for one company were extracted. The sample size also excluded small and medium-sized enterprises with particularly small numbers of employees and cases where the percentage of population restoration exceeded $100 \%$ due to a noticeable number of employees despite an adequate level of samples.

Table 1 shows the basic statistics focusing on the characteristics of the analytical variables. Note that corporate attributes represent statistical data based on original samples, but employees' attributes include statistics after the population restoration was conducted. 
Table 1. Summary of statistics (mean)

\begin{tabular}{|c|c|c|c|}
\hline & Variables & $\begin{array}{c}\text { Means (the rate of } 1 \\
\text { in the case of dummy } \\
\text { variables) }\end{array}$ & $\begin{array}{c}\text { Standard deviation } \\
\text { (except dummy } \\
\text { variables) }\end{array}$ \\
\hline \multirow{9}{*}{$\begin{array}{l}\text { Corporate } \\
\text { attributes }\end{array}$} & Number of employees & 1046266.00 & 2178651.00 \\
\hline & Foreign-owned companies & 0.15 & - \\
\hline & Pharmaceutical companies & 0.61 & - \\
\hline & Labor unions & 0.46 & - \\
\hline & Percentage of female employees & 0.31 & 0.15 \\
\hline & $\begin{array}{l}\text { Sales per employee (males included) } \\
\text { unit: } 10,000 \text { yen }\end{array}$ & 4252.12 & 8089.22 \\
\hline & Extent of WLB systems & 1.08 & 0.69 \\
\hline & Female career development through job & 0.08 & - \\
\hline & Particular training for female employees & 0.12 & - \\
\hline \multirow{6}{*}{$\begin{array}{l}\text { Female } \\
\text { employees' } \\
\text { attributes }\end{array}$} & Number of years of education & 14.23 & 0.01 \\
\hline & Marriage & 0.29 & \\
\hline & Employment years & 5.77 & 0.15 \\
\hline & Pre-tax annual income & 407.55 & 149.42 \\
\hline & Managerial position & 1.10 & 0.36 \\
\hline & Motivation level (four categories) & 2.26 & 0.01 \\
\hline
\end{tabular}

The average number of employees is $1,046,266$, which suggests that the data included relatively large companies. The $15.2 \%$ percentage of foreign-owned companies is characteristic of this industry. The pharmaceutical preparation and manufacturing industry represents $61.3 \%$ of the sample size. Companies with labor unions represented $45.8 \%$, which implies that almost half of the companies have labor unions. The percentage of female employment including part-time employees is $31 \%$. Sales per employee (including male workers) are high at $42,521,210$ yen.

The category of WLB considers to what extent companies have the following four WLB systems: a nursing care leave system, a child care leave system, a children's day care facility at the workplace, and a home caregiver dispatching system. We assign one standard numerical point for each item provided. The table shows the total items with a maximum of four. The average is 1.08 , which suggests that companies implement just one of the four systems on average. Furthermore, only $7.7 \%$ of the companies introduce a career development system through female job rotation and $11.9 \%$ have specific job training methods for women. These results imply that few companies implement substantial measures for active utilization of female employees.

The values for female workers are based on an employee awareness survey of full-time employees. The average number of years for employee education is 14.23 ; the percentage of married women is $29.4 \%$, and the average duration of service is 5.77 years. For managerial position indexes, ordinary workers are set as 1 , project manager and subsection chief are set as 2 , and section chief is set as 3 . The findings from the samples show that no women are in a position higher than section chief. The average number is 1.10 , which suggests that most of the samples are ordinary workers. The average annual income is 4,075,450 yen. With respect to the "job motivation" category, we set "not motivated at all" as 1 , "not motivated so much" as 2, "moderately motivated" as 3, and "highly motivated" as 4 . The average is 2.26 , which is indicative of low motivation.

Moreover, Table 2 shows the percentage of women in managerial positions by occupational field. 
Table 2. Percentage of managerial personnel by gender and functional area

\begin{tabular}{l|cc}
\hline \multicolumn{1}{c|}{ Functional Area } & $\begin{array}{c}\text { The percentage of male } \\
\text { managerial personnel }\end{array}$ & $\begin{array}{c}\text { The percentage of female } \\
\text { managerial personnel }\end{array}$ \\
\hline R \& D & 28.60 & 2.49 \\
MR & 27.92 & 0.85 \\
Production and distributior & 11.86 & 0.30 \\
Indirect sector & 43.86 & 2.11 \\
\hline Total (\%) & 24.84 & 1.21 \\
\hline
\end{tabular}

Note: R\&D refers to research and development. MR refers to medical representative.

The average percentage of female promotions to managerial positions is $1.21 \%$. This is remarkably low compared to the male percentage of $24.84 \%$. There are considerable differences according to job type; a relatively high percentage of female promotions to managerial positions is noted in research and development (R\&D) and indirect sectors. However, a comparison in the indirect sector of the female percentage with that of men in managerial positions suggests that female promotions in the indirect area remain inactive. In the meantime, the female promotion percentage in medical representative (MR) or sales operations is exceedingly low. The characteristics of this category, such as the burden of an outside job and long working hours, make it particularly difficult for female workers to contribute.

We consider female promotion factors exclusively from the perspective of personnel management, similar to many preceding studies, before conducting SEM modeling analysis. We focus on the R\&D and indirect sectors where there are adequate samples, and the percentages of female promotions to managerial positions are higher. The analyses use the three job categories of female employees as dependent variables, establish "ordinary workers" as a standard criterion, and apply an ordered probit model.

Table 3 shows the estimation results for female promotion in the R\&D sector. As expected, age is a factor and has a positive effect on female promotion. Marriage has a significantly negative effect at the $10 \%$ level. For personnel measures, the award system for tenure and the annual salary system are effective for female promotions. In foreign-owned companies, female employees are likely to be promoted. In addition, the percentage of female workers in managerial positions is low for head offices in Tokyo and Osaka. Labor unions is a negative factor, but it is not statistically significant.

Table 3. Decisive factors for female promotion in the R\&D sectors

\begin{tabular}{|c|c|c|c|}
\hline Independent Variable & Coefficient $\mathrm{St}$ & d Error & \\
\hline$\overline{\text { Age }}$ & 0.312 & 0.085 & *** \\
\hline Married $=1$, others $=0$ & -0.879 & 0.445 & * \\
\hline Award system for long service $(\mathrm{yes}=1, \mathrm{no}=$ & 2.278 & 0.524 & *** \\
\hline Annual salary system $($ yes $=1$, no $=0$ ) & 1.084 & 0.520 & * \\
\hline Reemployment system $($ yes $=1$, no $=0)$ & 1.017 & 0.723 & \\
\hline Fixed workplace system $($ yes $=1$, no $=0)$ & 0.887 & 0.567 & \\
\hline Head office in Tokyo & -2.467 & 0.640 & *** \\
\hline Head office in Osaka & -1.184 & 0.360 & ** \\
\hline Foreign-owned companies & 3.778 & 0.923 & *** \\
\hline Labor unions (yes $=1$, no $=0$ ) & -0.355 & 0.245 & \\
\hline Sample size & 159 & & \\
\hline Wald $X^{2}(10)$ & 56.020 & & \\
\hline $\mathrm{P}>\mathrm{X}^{2}(10)$ & 0.000 & & \\
\hline Pseudo $\mathrm{R}^{2}$ & 0.696 & & \\
\hline
\end{tabular}


Table 4. Factors deciding female promotion in the indirect sectors

\begin{tabular}{|c|c|c|c|}
\hline Independent Variable & Coefficient & Standard Error & \\
\hline Number of years of education & 0.302 & 0.140 & * \\
\hline Graduation from the pharmaceutical department & -0.883 & 0.385 & ** \\
\hline Age & 1.001 & 0.050 & * \\
\hline Married $=1$, others $=0$ & 0.181 & 0.052 & *** \\
\hline Management by objectives $($ yes $=1$, no $=0)$ & 0.609 & 0.320 & \\
\hline Promotion test system $($ yes $=1$, no $=0)$ & -0.469 & 0.310 & \\
\hline Feedback on performance evaluation $(\mathrm{yes}=1, \mathrm{no}=0$ ) & -1.088 & 0.355 & $* * *$ \\
\hline Nursery care leave system $($ yes $=1$, no $=0$ ) & -0.735 & 0.205 & *** \\
\hline Child care leave system $($ yes $=1$, no $=0)$ & 1.277 & 0.600 & * \\
\hline Short-time service and fixed workday system (yes $=1$, no & 0.583 & 0.254 & * \\
\hline Fixed workplace system $($ yes $=1$, no $=0)$ & -0.343 & 0.246 & \\
\hline Particular training for female employees (yes $=1, \mathrm{no}=0$ ) & 1.399 & 0.215 & *** \\
\hline Career development through job rotation $(y e s=1$, no $=0)$ & 0.504 & 0.380 & \\
\hline Sample size & 358 & & \\
\hline Wald $X^{2}(13)$ & 70.42 & & \\
\hline $\mathrm{P}>\mathrm{X}^{2}(13)$ & 0.000 & & \\
\hline Pseudo $\mathrm{R}^{2}$ & 0.439 & & \\
\hline
\end{tabular}

Table 4 presents the results in the indirect sector. The number of years of education is a significant factor. Unexpectedly, however, graduation from a pharmaceutical department is a negative factor in the indirect sector of pharmaceutical companies. This suggests that specialized pharmaceutical knowledge is less important for promotion in the indirect sector. Age is positively significant as is the case for the $\mathrm{R} \& \mathrm{D}$ sector, but marriage has a positive effect in contrast to the R\&D sector. For personnel management, feedback on employee performance evaluation is a negative factor. Management by objective is a positive factor, and feedback on performance evaluation is a negative factor. However, both items are statistically insignificant. With respect to WLB policies, the nursing care leave system is a negative factor, whereas the child care leave system, the short-hour service, and the fixed workday system are positively significant at the $10 \%$ level. Training programs for female workers are a positive factor for promotion. Thus, WLB policies and particular training for female employee effectively work only for indirect female employees.

As noted in Tables 3 and 4, there are no consistent causalities observed between personnel measures and female promotion patterns. In addition, WLB policies are not a significant factor for the R\&D sector. At the same time, the nursing care leave system is a negative factor, while the child care leave system is a positive factor for the indirect sector. Moreover, marriage has contrasting effects in the two sectors, and consistent explanatory variables are observed only for age.

Table 5 displays the results of the structural equation model for further investigation. The path coefficient from WLB policies to the percentage of female workers shows a negative effect. This result indicates that if companies perceive enormous costs to implement WLB policies, they are likely to employ fewer women to avoid the financial burden. Conversely, the path coefficient from the percentage of female employees to WLB policies is a positive value. That is, these companies introduce WLB polices to meet the needs of many female workers.

On the other hand, WLB policies have a considerably negative direct impact on sales per employee. Employees who use the child rearing leave and nursery care programs retain their positions as employees during the leave period. Although they provide virtually no service to the company during leave, the total number of corporate employees does not change. In another case, the number of workers often increases due to the employment of supplementary staff, but they may not have an effect on improving corporate performance.

In contrast, sales per employee have a positive impact on WLB policies. This suggests that enterprises that achieve high performance can afford to allocate business resources to WLB policies. WLB policies do not have a direct effect on female promotion, and a significantly negative coefficient is observed. However, the policies have an effect and increase female working years, which indirectly benefits female workers. This is because 
longer tenure years lead to promotion, and promotion causes wage raises. Some analyses of the positive effect of WLB policies on wage raises and promotions reflect these indirect effects.

For the effects of other female-related measures, "career development through female job rotation" has a negative effect on "rising through the ranks to higher posts" but is not statistically significant. In addition, the effect of "job training systems for female employees" on "motivation" is positive but not significant and is not effective in promoting female workers to higher positions.

Table 5. Results of structural equation modeling

\begin{tabular}{|c|c|c|c|c|c|}
\hline Exogenous Variables & & Endogenous Variables & Coefficient & $\begin{array}{l}\text { Standard } \\
\text { Error }\end{array}$ & \\
\hline Number of years of education & $--->$ & Managerial position & 0.061 & 0.024 & $* * *$ \\
\hline Married dummy & $--->$ & Managerial position & -0.101 & 0.902 & \\
\hline Number of employees & $--->$ & Sales per employee & 0.915 & 0.320 & $* * *$ \\
\hline Number of employees & $--->$ & Particular training for female employees & $1.3 \mathrm{E}-03$ & $0.2 \mathrm{E}-04$ & $* * *$ \\
\hline Foreign-owned companies & $--->$ & $\begin{array}{l}\text { Female career development through job } \\
\text { rotation }\end{array}$ & -0.089 & 0.050 & \\
\hline Foreign-owned companies & $--->$ & WLB policies & -0.549 & 0.065 & $* * *$ \\
\hline Foreign-owned companies & $--->$ & Managerial position & 0.012 & 0.098 & \\
\hline Pharmaceutical manufacturer & $--->$ & Percentage of female employees & -0.189 & 0.152 & \\
\hline Pharmaceutical manufacturer & $--->$ & Managerial position & -0.189 & 0.869 & $* * *$ \\
\hline Percentage of female employees & $--->$ & Particular training for female employees & 0.706 & 0.261 & $* * *$ \\
\hline Percentage of female employees & $--->$ & WLB policies & 2.527 & 1.009 & $* * *$ \\
\hline Percentage of female employees & $--->$ & Managerial position & 0.452 & 0.165 & $* * *$ \\
\hline Sales per employee & $--->$ & Particular training for female employees & $1.5 \mathrm{E}-03$ & $0.4 \mathrm{E}-04$ & $* * *$ \\
\hline Sales per employee & $--->$ & WLB policies & $1.5 \mathrm{E}-03$ & $0.2 \mathrm{E}-04$ & $* * *$ \\
\hline Labor unions & $--->$ & WLB policies & 0.875 & 0.321 & $* * *$ \\
\hline $\begin{array}{l}\text { Female career development through job } \\
\text { rotation }\end{array}$ & $--->$ & Managerial position & -0.046 & 0.029 & \\
\hline Particular training for female employees & $--->$ & Motivation & 0.159 & 0.108 & \\
\hline Particular training for female employees & $--->$ & Managerial position & -0.034 & 0.029 & \\
\hline WLB policies & $--->$ & Percentage of female employees & -0.046 & 0.015 & $* * *$ \\
\hline WLB policies & $--->$ & Sales per employee & -2282.35 & 968.24 & $* * *$ \\
\hline WLB policies & $--->$ & Employment years & 1.693 & 1.532 & \\
\hline WLB policies & $--->$ & Managerial position & -0.032 & 0.012 & $* * *$ \\
\hline Employment years & $--->$ & Managerial position & 0.025 & 0.009 & $* * *$ \\
\hline Employment years & $--->$ & Pretax annual income (unit: 10,000 yen) & 9.812 & 2.652 & $* * *$ \\
\hline Promotion to subsection chief and higher & $--->$ & Motivation & 0.02 & 0.018 & \\
\hline Promotion to subsection chief and higher & $--->$ & Pre-tax annual income (unit: 10,000 yen) & 128.64 & 59.2 & $* * *$ \\
\hline Pre-tax annual income (unit: 10,000 yen) & $--->$ & Motivation & 0.001 & $0.3 \mathrm{E}-03$ & $* * *$ \\
\hline
\end{tabular}

\section{Conclusion}

This study examined matched data based on the Fact-finding Survey on Employment Management and the Survey on The Employees' Awareness, focusing on companies listed in the Report on the Employment Promotion Measures for the Pharmaceutical Industry to analyze the effect of intra-corporate policies on female employment. These data enabled us to collect information on corporate measures from companies and information on the distinctive attributes and behaviors of individual workers from employees.

We first examined the relationships among variables affecting female promotion in R\&D and indirect sectors using an ordered probit model before conducting SEM model analyses. However, we could not find any consistent causality for the effect of personnel measures, including WLB policies, on female promotion patterns. WLB policies and particular training for female employees effectively work only for indirect female employees. 
Next, the SEM estimation results treating the complicated relationships among variables indicate that there were no noticeable results, implying that WLB policies are effective for boosting productivity. In addition, we demonstrated that WLB policies do not have a direct impact on female promotion and payment levels, but they are effective in increasing female employment years. Longer tenure is likely to facilitate female promotion and increase their wages.

Previous studies have not substantially considered the causalities of the variables in intra-corporate policies and personnel management. Our research identified the probability of WLB policies not affecting corporate productivity, and that these policies indirectly affect women's wages through their promotion, based on SEM analysis that could make a consideration for these causalities. However, these examination results are based on the pharmaceutical industry and data obtained in the early phase of increased demand for competitive performance evaluation systems and WLB policies. For future research, it is essential to analyze updated data and assess policy effects with a focus on a wider range of areas in a recent situation where WLB policies are more widespread.

\section{Acknowledgments}

We would like to express our deepest gratitude for the financial support from Grant-in-Aid for Scientific Research C and the data set from Professor Hisakazu Matushige at Osaka University, Japan.

\section{References}

Beauregard, T. A., \& Henry, L. C. (2009). Making the link between work-life balance practices and organizational performance. Human Resource Management Review, 19(1), 9-22. https://doi.org/10.1016/j.hrmr.2008.09.001

Brigham N. L., Kelso, K. A., Jackson M.A., \& Smith R. H. (1997). The role of invidious comparisons and deservingness in sympathy and schadenfreude. Basic and Applied Psychology, 19(3), 363-380. https://doi.org/10.1207/s15324834basp1903_6

Cabinet Office. (2017). Gender Equality White Paper. Retrieved from http://www.gender.go.jp/about_danjo/whitepaper/h29/zentai/index.html

Fresko, B. (1997). Attitudinal change among university student tutors. Journal of Applied Social Psychology, 27(14), 1277-1301. https://doi.org/10.1111/j.1559-1816.1997.tb01806.x

Fuchs, R. (1996). Causal models of physical participation: Testing the predictive power of the construct "pressure to change. Journal of Applied Social Psychology, 26(21), 1931-1960. https://doi.org/10.1111/j.1559-1816.1996.tb00106.x

Greenhaus, J. H., \& Parasuraman, S. (1999). Research on work, family, and gender: Current status and future direction. In G. N. Powel (Ed.), Handbook of gender and work (pp. 391-412). Newbury Park, CA: Sage. https://doi.org/10.4135/9781452231365.n20

Hammer, L., Allen, E., \& Grigsby, T. (1997). Work-family conflict in dual-earner couples: Within-individual and crossover effects of work and family. Journal of Vocational Behaviour, 50(2), 185-203. https://doi.org/10.1006/jvbe.1996.1557

Higuchi, Y. (1991). The Japanese economy and employment behavior. Japan: Toyo Keizai Inc.

Higuchi, Y., Asami, Y., Hirakawa, S., Ōzeki, Y., \& Mori, T. (2006). Two myths and one truth. In Y. Higuchi and the Policy Research Institute, Ministry of Finance (Eds.), Introduction of declining birthrates and Japan's economy and society (pp. 1-21). Japan: Nippon Hyoron Sha Co., Ltd.

Joreskog, K. G. (1969). A general approach to confirmatory maximum likelihood factor analysis. Psychometrika, 34(2), 183-201. https://doi.org/10.1007/BF02289343

Joreskog, K. G. (1978). Structural analysis of covariance and correlation matrices. Psychometrika, 43(4), 443-477. https://doi.org/10.1007/BF02293808

Joreskog, K. G., \& Lawley, D. N. (1968). New methods in maximum likelihood factor analysis. British Journal of Mathematical and Statistical Psychology, 21, 85-96. https://doi.org/10.1111/j.2044-8317.1968.tb00399.x

Lobel S. A. (1999). Impacts of diversity and work-life initiatives in organizations. In G. N. Powell (Ed.), Handbook of gender and work (pp. 453-476). Newbury Park, CA: Sage. https://doi.org/10.4135/9781452231365.n23

Lobel S. A., \& Kossek E. E. (1996). Human resource strategies to support diversity in work and personal 
lifestyles: Beyond the "family friendly" organization. In E.E. Kossek \& S.A. Lobel (Eds.), Managing diversity: Human resource strategies for transforming the workplace (pp. 221-243). Cambridge, MA: Blackwell.

Maurer K. L., Park B., \& Judd, C. M. (1996). Stereotypes, prejudice, and judgments of group members: The mediating role of public policy decisions. Journal of Experimental Social Psychology, 32, 411-436. https://doi.org/10.1006/jesp.1996.0019

Mitani, N. (1996). Female employment after the enactment of the equal employment opportunity law. Journal of the Japan Institute of Labor, 443, 24-36.

Morita, Y., \& Kaneko, Y. (1998). The prevalence of the child-care leave system and female service years. The Japanese Journal of Labor Studies, 459, 50-62.

Ōsawa, M. (1993). Changes in the labor market of female college and university graduates. The Japanese Journal of Labor Studies, 405, 24-33.

Parasuraman, S., Purohit, Y. S., Godshalk, V. M., \& Beutell, N. J. (1996). Work and family variables, entrepreneurial career success, and psychological well-being. Journal of Vocational Behavior, 48, 275-300. https://doi.org/10.1006/jvbe.1996.0025

Perry-Smith, J. E., \& Blum, T. C. (2000). Work-family human resource bundles and perceived organizational performance Academy of Management Journal, 43(6), 1107-1117.

Richard, R. van der Pligt, J, \& de Vries, N. (1996). Anticipated affect and behavioral choice. Basic and Applied Social Psychology, 18(2), 111-130. https://doi.org/10.1207/s15324834basp1802_1

Sakazume, H. (2002). Impacts of family-friendly practices on employee attitude and organizational performance. The Japanese Journal of Labor Studies, 503, 29-42.

Shepard III, M. S., Clifton, T. J., \& Kruse, D. (1996). Flexible work hours and productivity: Some evidence from the pharmaceutical industry. Industrial Relations, 35(1), 123-139.

Shigeno, Y., \& Ōkusa, Y. (1998). The effect of the child-care leave system on female marriage and continuous employment. The Japanese Journal of Labor Studies, 459, 39-49.

Takeishi, E. (2006). The significance of work-family policies for companies: Focusing on the study on the effect of work-family policies, The Japanese Journal of Labor Studies, 553, 19-33.

Taylor, S., \& Todd, P. (1997). Understanding the determinants of consumer composting behavior. Journal of Applied Social Psychology, 27(7), 602-628. https://doi.org/10.1111/j.1559-1816.1997.tb00651.x

Tomita, Y. (1988). Female employment management and wage differentials between male and female workers. In K. Koike \& Y. Tomita (Eds.), Workplace female employees with remarkable careers. Japan: Toyo Keizai Inc.

Wakisaka, A. (2006). What do family-friendly companies and workplaces mean? Their relationships with equal employment opportunities and corporate performances. Quarterly Journal of Domestic Economy, 71, 17-28.

Yamamoto, I., \& Matsuura T. (2014). Effect of work-life balance practices on firm productivity: Evidence from Japanese firm-level panel data. RIETI Discussion Paper Series, 12-E-079. https://doi.org/10.1515/bejeap-2013-0186

\section{Copyrights}

Copyright for this article is retained by the author(s), with first publication rights granted to the journal.

This is an open-access article distributed under the terms and conditions of the Creative Commons Attribution license (http://creativecommons.org/licenses/by/4.0/). 